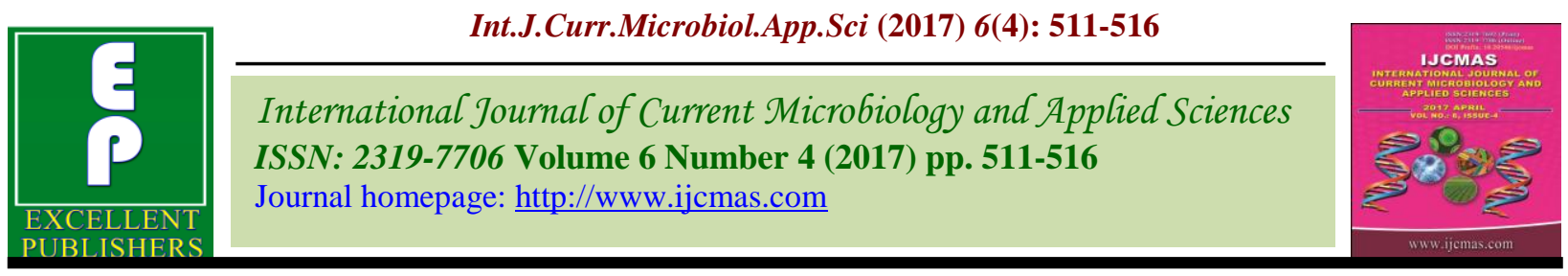

Original Research Article

https://doi.i.org/10.20546/ijcmas.2017.604.061

\title{
Effect of Integrated Nutrient Management (INM) practices on Growth, Yield and Oil Yield of Safflower (Carthamus tinctorius $\mathbf{L}$.)
}

\author{
Ripan Chandra Das ${ }^{1}$, G. Somanagouda ${ }^{2}$ and Bheiru Singh ${ }^{1}$ \\ ${ }^{1}$ Department of Agronomy, UAS, Dharwad, Karnataka- 580005, India \\ ${ }^{2}$ Department of Agronomy, ARS, Annigari, UAS, Dharwad, Karnataka- 580005, India \\ *Corresponding author
}

\section{A B S T R A C T}

\begin{tabular}{l} 
K e y w o r d s \\
Safflower, \\
Integrated nutrient \\
management, \\
Vermicompost, \\
Azospirillum, PSB, \\
Oil yield, Yield. \\
Article Info \\
\hline Accepted: \\
06 March 2017 \\
Available Online: \\
10 April 2017
\end{tabular}

Keywords

Safflower,

Integrated nutrient

management,

Vermicompost

Azospirillum, PSB

Oil yield, Yield.

Article Info

Accepted:

Available Online:

10 April 2017

\section{Introduction}

Safflower (Carthamustinctorius L.) is one of the oldest crop cultivated for its edible seed oil and is known for salt as well as drought tolerance crop due to partially xerophytic nature, in addition to deep and extensive root system making efficient use of reserved soil moisture. The average productivity of safflower is low in India $\left(627 \mathrm{~kg} \mathrm{ha}^{-1}\right)$ while it is relatively better in Karnataka $\left(822 \mathrm{~kg} \mathrm{ha}^{-1}\right)$. As the crop is mainly cultivated under rainfed condition during post-rainy season on receding soil moisture, results in inadequate supply of both water and nutrients to the crop. Application of limited quantity of nutrients (NPK) only through chemical fertilizer creates multiple-nutrients deficiencies in the soil which is considered as one of reason for limiting the crop production (Tiwari et al., 2002). Hence, there is need to be improved the soil fertility for better yield. Thus, soil fertility as well as crop production can be improved by application of nutrients through organic sources and/or integration of different organic sources of nutrients (Reddy 2005; Akbari et al., 2011; Basak et al., 2012). Therefore, combined application of organic manure and chemical fertilizers may enhance the productivity and economic profitability of safflower. In this regard, a study was conducted to test the effect of combined 
application of inorganic fertilizers with organic manures including microbial sources on productivity of safflower under dryland conditions.

\section{Materials and Methods}

A field experiment was conducted at the Agricultural Research Station, Annigeri, University of Agricultural Sciences, Dharwad, during rabi season of 2015-16. The experiment was laid out in a randomized complete block design (RCBD) with three replications and ten treatments comprising, $\mathrm{T}_{1}$ - RDF (40:40:12 kg ha ${ }^{-1}$ NPK) + FYM (5.0 t $\left.\mathrm{ha}^{-1}\right), \mathrm{T}_{2}-\mathrm{RDF}\left(40: 40: 12 \mathrm{~kg} \mathrm{ha}^{-1} \mathrm{NPK}\right)$ alone, $\mathrm{T}_{3}-50 \% \mathrm{RDF}+1.0 \mathrm{t} \mathrm{ha}^{-1}$ Vermicompost + Azospirillum $+\mathrm{PSB}, \mathrm{T}_{4}-\mathrm{RDF}+1.0 \mathrm{t} \mathrm{ha}^{-1}$ Vermicompost + Azospirillum $+\mathrm{PSB}, \mathrm{T}_{5}-$ $50 \% \mathrm{RDF}+2.0 \mathrm{t} \mathrm{ha}^{-1}$ Vermicompost + Azospirillum $+\mathrm{PSB}, \mathrm{T}_{6}-\mathrm{RDF}+2.0 \mathrm{t} \mathrm{ha}^{-1}$ Vermicompost + Azospirillum $+\mathrm{PSB}, \mathrm{T}_{7}-$ $50 \% \mathrm{RDF}+1.0 \mathrm{t} \mathrm{ha}^{-1}$ Vermicompost + Azospirillum $+\mathrm{PSB}+\mathrm{ZnSO}_{4} 10.0 \mathrm{~kg} \mathrm{ha}^{-1} \mathrm{~T}_{8}-$ $\mathrm{RDF}+1.0 \mathrm{t} \mathrm{ha}^{-1}$ Vermicompost + Azospirillum + PSB + $\mathrm{ZnSO}_{4} @ 10.0 \mathrm{~kg} \mathrm{ha}^{-1}$, $\mathrm{T}_{9}-50 \% \mathrm{RDF}+2.0 \mathrm{t} \mathrm{ha}^{-1}$ Vermicompost + Azospirillum + PSB + $\mathrm{ZnSO}_{4} @ 10.0 \mathrm{~kg} \mathrm{ha}^{-1}$ and $\mathrm{T}_{10^{-}} \mathrm{RDF}+2.0 \mathrm{t} \mathrm{ha}^{-1}$ Vermicompost + Azospirillum + PSB + $\mathrm{ZnSO}_{4} @ 10.0 \mathrm{~kg} \mathrm{ha}^{-1}$. The soil of the experimental field was clayey in texture and soil in low, low and high rating for available nitrogen $\left(224 \mathrm{~kg} \mathrm{~N} \mathrm{ha}^{-1}\right.$ ) (Kjeldal method), available phosphorus $\left(20.86 \mathrm{~kg} \mathrm{P}_{2} \mathrm{O}_{5}\right.$ $\mathrm{ha}^{-1}$ ) (Olesen's method) and available potassium (342 $\left.\mathrm{kg} \quad \mathrm{K}_{2} \mathrm{O} \quad \mathrm{ha}^{-1}\right) \quad$ (Flame photometric method), respectively. The soil was found slightly alkaline ( $\mathrm{pH}$ 7.95) (Potentiometric method) with normal electric conductivity. Urea, single super phosphate, muriate of potash and zinc sulphate as chemical sources of nutrients, and FYM, Vermicompost, Azspirillum, and PSB as organic and biofertilizer sources were used in different combinations to make 10 treatments as mentioned above. The chemical fertilizers were applied as basal at the time of sowing and for seed treatment the seeds of safflower were coated with Azospirillum and PSB one hour before sowing and they were air dried under shade whereas the organic manures were applied three weeks before sowing of safflower. Safflower variety- Annigeri-1 was sown in the second week of October and harvested in the third week of February. Rainfall received during 2015-16 was 507.20 $\mathrm{mm}$ which was $67.24 \%$ lower than the longterm average of $754.90 \mathrm{~mm}$. During the crop growth period from October to February only $38 \mathrm{~mm}$ rainfall received in October month at the time of sowing. Further, no rainfall was received during the crop growth period. The oil content of safflower seed was estimated by using Nuclear Magnetic Resonance (NMR).

\section{Results and Discussion}

\section{Effect of INM on growth, yield and quality parameters}

The experimental results showed significantly effect of INM approach on growth parameters viz. plant height, primary and secondary branches of safflower over only chemical method at harvest (Table 1). Results indicated that among different INM approach, application of $\mathrm{RDF}+2.0 \mathrm{t} \mathrm{ha}^{-1}$ Vermicompost + Azospirillum + PSB + $\mathrm{ZnSO}_{4} @ 10.0 \mathrm{~kg} \mathrm{ha}^{-1}$ $\left(\mathrm{T}_{10}\right)$ recorded significantly highest plant height $(75.14 \mathrm{~cm})$, primary $\left(12.07\right.$ plant $\left.^{-1}\right)$ and secondary branches (15.87 plant $\left.^{-1}\right)$, but integrated nutrients management treatments $\mathrm{T}_{6}, \mathrm{~T}_{7}, \mathrm{~T}_{8}$ and $\mathrm{T}_{9}$ found to be at par with $\mathrm{T}_{10}$. This was due to adequate combined application of organic manure and inorganic fertilizers which were directly involved in cell multiplication and vigorous root system development for effective absorption of applied nutrients, whereas zinc sulphate resembles nitrogen in being able to improve cell division, cell elongation as well as having a favourable effect in chlorophyll synthesis. The results corroborate with the finding of Babalad (1999) and Kumar et al., 2015. 
Table.1 Effect of INM practices on growth parameters, yield attributes, yield and quality as influenced by different treatments at harvest of safflower

\begin{tabular}{|c|c|c|c|c|c|c|c|c|c|c|c|}
\hline & \multicolumn{3}{|c|}{ Growth parameters } & \multicolumn{6}{|c|}{ Yield attributes } & \multicolumn{2}{|c|}{ Quality parameters } \\
\hline Treatments & $\begin{array}{c}\text { Plant } \\
\text { height } \\
(\mathbf{c m})\end{array}$ & $\begin{array}{l}\text { Primary } \\
\text { branches }\end{array}$ & $\begin{array}{c}\text { Secondary } \\
\text { branches }\end{array}$ & $\begin{array}{l}\text { Capsules } \\
\left(\text { plant }^{-1}\right)\end{array}$ & $\begin{array}{l}\text { Seed weight } \\
\left(\text { g plant }^{-1}\right)\end{array}$ & $\begin{array}{c}100 \text { seed } \\
\text { weight } \\
(\mathrm{g})\end{array}$ & $\begin{array}{l}\text { Seed yield } \\
\left(\mathrm{kg} \mathrm{ha}^{-1}\right)\end{array}$ & $\begin{array}{c}\text { Stalk } \\
\text { yield } \\
\left(\mathrm{kg} \mathrm{ha}^{-1}\right)\end{array}$ & $\begin{array}{l}\text { Harvest } \\
\text { index }\end{array}$ & $\begin{array}{c}\text { Oil } \\
\text { content } \\
(\%)\end{array}$ & $\begin{array}{l}\text { Oil yield } \\
\left(\mathrm{kg} \mathrm{ha}^{-1}\right)\end{array}$ \\
\hline $\mathrm{T}_{1}$ & 68.82 & 9.27 & 11.73 & 24.40 & 18.02 & 5.13 & 831 & 2763 & 0.23 & 27.11 & 225.12 \\
\hline $\mathrm{T}_{2}$ & 68.29 & 9.13 & 11.40 & 24.20 & 17.36 & 5.02 & 773 & 2628 & 0.23 & 27.06 & 209.33 \\
\hline $\mathrm{T}_{3}$ & 69.23 & 9.73 & 12.73 & 24.87 & 18.32 & 5.23 & 834 & 2867 & 0.23 & 27.41 & 229.04 \\
\hline $\mathrm{T}_{4}$ & 69.11 & 9.33 & 12.40 & 24.73 & 18.19 & 5.21 & 833 & 2769 & 0.23 & 27.35 & 226.54 \\
\hline $\mathrm{T}_{5}$ & 70.83 & 10.07 & 13.20 & 25.07 & 19.00 & 5.30 & 850 & 2923 & 0.23 & 27.73 & 235.16 \\
\hline $\mathrm{T}_{6}$ & 71.59 & 11.27 & 14.67 & 26.20 & 20.54 & 5.51 & 904 & 3082 & 0.23 & 28.41 & 256.55 \\
\hline $\mathrm{T}_{7}$ & 72.77 & 11.47 & 14.80 & 27.60 & 20.78 & 5.94 & 935 & 3146 & 0.23 & 28.48 & 266.46 \\
\hline $\mathrm{T}_{8}$ & 73.45 & 11.53 & 15.53 & 27.73 & 20.95 & 6.01 & 945 & 3169 & 0.23 & 28.52 & 269.84 \\
\hline $\mathrm{T}_{9}$ & 74.60 & 11.67 & 15.60 & 28.13 & 21.04 & 6.06 & 950 & 3204 & 0.22 & 28.57 & 271.47 \\
\hline $\mathrm{T}_{10}$ & 75.14 & 12.07 & 15.87 & 28.27 & 21.45 & 6.11 & 989 & 3316 & 0.23 & 28.65 & 283.32 \\
\hline S.Em \pm & 2.12 & 0.31 & 0.47 & 1.05 & 0.81 & 0.25 & 41.31 & 116.20 & 0.01 & 0.81 & 13.18 \\
\hline $\begin{array}{c}\text { C.D } \\
(\mathrm{P}=0.05)\end{array}$ & 4.11 & 0.93 & 1.41 & 3.12 & 2.39 & 0.76 & 122.75 & 345.25 & NS & NS & 39.17 \\
\hline
\end{tabular}


Table.2 Effect of INM practices on economics of safflower

\begin{tabular}{|c|c|c|c|c|}
\hline Treatments & $\begin{array}{c}\text { Cost of } \\
\text { cultivation (Rs. } \\
\left.\text { ha }^{-1}\right)\end{array}$ & $\begin{array}{l}\text { Gross returns } \\
\quad\left(\text { Rs. } \text { ha }^{-1}\right)\end{array}$ & $\begin{array}{l}\text { Net returns (Rs. } \\
\left.\text { ha }^{-1}\right)\end{array}$ & B:C ratio \\
\hline $\mathrm{T}_{1}-\mathrm{RDF}\left(40: 40: 12 \mathrm{~kg} \mathrm{ha}^{-1} \mathrm{NPK}\right)+\mathrm{FYM}\left(5.0 \mathrm{t} \mathrm{ha}^{-1}\right)$ & 17555 & 23266 & 5711 & 1.33 \\
\hline $\mathrm{T}_{2}-\mathrm{RDF}\left(40: 40: 12 \mathrm{~kg} \mathrm{ha}^{-1} \mathrm{NPK}\right)$ & 15055 & 21657 & 6602 & 1.44 \\
\hline $\mathrm{T}_{3}-50 \% \mathrm{RDF}+1.0 \mathrm{tha}^{-1} \mathrm{VC}+$ Azospirillum $+\mathrm{PSB}$ & 15769 & 23363 & 7594 & 1.48 \\
\hline $\mathrm{T}_{4}-\mathrm{RDF}+1.0 \mathrm{tha}^{-1} \mathrm{VC}+$ Azospirillum $+\mathrm{PSB}$ & 17115 & 23333 & 6218 & 1.36 \\
\hline $\mathrm{T}_{5}-50 \% \mathrm{RDF}+2.0 \mathrm{t} \mathrm{ha}^{-1} \mathrm{VC}+$ Azospirillum $+\mathrm{PSB}$ & 17769 & 23808 & 6039 & 1.34 \\
\hline $\mathrm{T}_{6}-\mathrm{RDF}+2.0 \mathrm{t} \mathrm{ha}^{-1} \mathrm{VC}+$ Azospirillum $+\mathrm{PSB}$ & 19115 & 25299 & 6184 & 1.32 \\
\hline $\begin{array}{l}\mathrm{T}_{7}-50 \% \mathrm{RDF}+1.0 \mathrm{t} \mathrm{ha}^{-1} \mathrm{VC}+\text { Azospirillum }+\mathrm{PSB}+\mathrm{ZnSO}_{4} \\
10.0 \mathrm{~kg} \mathrm{ha}^{-1}\end{array}$ & 16309 & 26186 & 9877 & 1.61 \\
\hline $\begin{array}{l}\mathrm{T}_{8}-\mathrm{RDF}+1.0 \mathrm{t} \mathrm{ha}^{-1} \mathrm{VC}+\text { Azospirillum }+\mathrm{PSB}+\mathrm{ZnSO}_{4} 10.0 \\
\mathrm{~kg} \mathrm{ha}^{-1}\end{array}$ & 17655 & 26446 & 8791 & 1.50 \\
\hline $\begin{array}{l}\mathrm{T}_{9}-50 \% \mathrm{RDF}+2.0 \mathrm{t} \mathrm{ha}^{-1} \mathrm{VC}+\text { Azospirillum }+\mathrm{PSB}+\mathrm{ZnSO}_{4} \\
10.0 \mathrm{~kg} \mathrm{ha}^{-1}\end{array}$ & 18309 & 26606 & 8297 & 1.45 \\
\hline $\begin{array}{l}\mathrm{T}_{10}-\mathrm{RDF}+2.0 \mathrm{t} \mathrm{ha}^{-1} \mathrm{VC}+\text { Azospirillum }+\mathrm{PSB}+\mathrm{ZnSO}_{4} 10.0 \\
\mathrm{~kg} \mathrm{ha}^{-1}\end{array}$ & 19655 & 27689 & 8034 & 1.41 \\
\hline S.Em \pm & -- & 1157 & 1157 & 0.07 \\
\hline C.D $(\mathrm{P}=0.05)$ & -- & 3437 & 3437 & 0.21 \\
\hline
\end{tabular}


Yield and quality parameters of safflower viz. capsules plant $^{-1}$, seed weight plant $^{-1}, 100$ seed weight, seed yield, stalk yield, oil content and oil yield significantly varied among various nutrients management treatments (Table 1). Results indicated that combined application of organic and inorganic fertilizers which helped in improvement of yield and quality parameters of safflower. Among different INM approach, application of RDF $+2.0 \mathrm{tha}$ 1 Vermicompost + Azospirillum + PSB + $\mathrm{ZnSO}_{4}$ @ $10.0 \mathrm{~kg} \mathrm{ha}^{-1}\left(\mathrm{~T}_{10}\right)$ recorded significantly highest capsules (28.27 plant $\left.^{-1}\right)$, seed weight (21.45 g plant $\left.^{-1}\right), 100$ seed weight $(6.11 \mathrm{~g})$, seed yield $\left(989 \mathrm{~kg} \mathrm{ha}^{-1}\right)$, stalk yield $\left(3316 \mathrm{~kg} \mathrm{ha}^{-1}\right)$ and oil yield (283.32 $\left.\mathrm{kg} \mathrm{ha}^{-1}\right)$ but integrated nutrients management treatments $\mathrm{T}_{6}, \mathrm{~T}_{7}, \mathrm{~T}_{8}$ and $\mathrm{T}_{9}$ found to be at par with $\mathrm{T}_{10}$. However, harvest index and oil content did not show any significant differences (Table 1). The higher yield and quality parameters of safflower in these treatments might be due to combination with organic sources which helped in sustaining nutrient supply and maintaining the residual soil moisture during dry period of crop growth, resulted in better utilization of applied nutrients through improved microbial activities that involved in nutrient transformation and fixation. Similar findings were reported by Malligawad (2010), Jalilian et al., (2012) and Yogesh (2013).

\section{Economics}

Economics significantly influenced by integrated nutrients management (Table 2). Among different INM treatments, treatment $\mathrm{T}_{7}$ (application of $50 \% \mathrm{RDF}+1.0 \mathrm{t} / \mathrm{ha}$ Vermicompost + Azospirillum + PSB + $\mathrm{ZnSO}_{4} 10.0 \mathrm{~kg} \mathrm{ha}^{-1}$ ) recorded significantly highest net returns ( $\square 9877 \mathrm{ha}^{-1}$ ) and B:C ratio (1.61) net returns due to lower cost of cultivation of this treatment and better utilization of resources. Results are in line with the findings by Naik (2008). However, application of RDF $+2.0 \mathrm{tha}^{-1}$ Vermicompost + Azospirillum + PSB + $\mathrm{ZnSO}_{4} @ 10.0 \mathrm{~kg} \mathrm{ha}^{-1}$ $\left(\mathrm{T}_{10}\right)$ recorded significantly highest gross returns ( $\square 27689 \mathrm{ha}^{-1}$ ), but, lower net returns and $\mathrm{B}: \mathrm{C}$ ratio due to highest cost of cultivation of this treatment.

Based on results of the field experiment, it seems quite logical to conclude that, potential and effective yield of safflower by integrated nutrients management Practices can be achieved by application of RDF $+2.0 \mathrm{t} \mathrm{ha}^{-1}$ Vermicompost + Azospirillum + PSB + $\mathrm{ZnSO}_{4} @ 10.0 \mathrm{~kg} \mathrm{ha}^{-1}\left(\mathrm{~T}_{10}\right)$, but economical yield can be achieved by application of $50 \%$ $\mathrm{RDF}+1.0 \mathrm{t} / \mathrm{ha}$ Vermicompost + Azospirillum $+\mathrm{PSB}+\mathrm{ZnSO}_{4} 10.0 \mathrm{~kg} \mathrm{ha}^{-1}$.

\section{References}

Jalillan, J., Modarres-Sanavy, S. A. M., Saberali, S. F., Sadat-Asilan, K. 2012. Effects of the combination of beneficial microbes and nitrogen on sunflower seed yields and seed quality traits under different irrigation regimes. J. Field Crops Res., 127: 2634.

Babalad, H. B. 1999. Integrated nutrient management for sustainable production in soybean based cropping systems. Ph. D. Thesis, Univ. Agric. Sci., Dharwad, Karnataka (India).

Malligawad, L. H. 2010. Effect of organics on the productivity of groundnut and its residual effects on succeeding safflower under rainfed farming situations. $19^{\text {th }}$ World Congress of Soil Science, Soil Solutions for a Changing World 1-6 August 2010, Brisbane, Australia, pp. 128-131.

Kumar, K., Vani, K. P., Srinivas, A., Surendrababu, P. 2015. Growth, yield and nutrient uptake of safflower as influenced by INM under irrigation and rainfed planting.Intl. J. Sci. Res., 
4(10): 179-187.

Naik, D. R., Halepyati, A. S., Pujari, B. T. 2008. Effects of organic manures and fertilizer levels on seed yield and economics of saflower (Carthamustinctorius L.). Karnataka J. Agric. Sci., 21(1): 104-105.

Reddy, S. S. 2005. Effect of different organic manures on available NPK status and organic Carbon after harvest of groundnut (Arachushypogaea L.). Crop Res., 30(1): 26-29.
2002. Long term influence of organic and inorganic fertilization on soil fertility and productivity of soybeanwheat system in vertisols. J. of Indian Society Soil Sci., 50(4): 472-475.

Yogesh, T. C. 2013. Effect of In-situ green manuring of legumes, NP levels and organic manures on growth, yield and quality of safflower. Ph.D. Thesis, Univ. Agric. Sci., Dharwad, Karnataka (India).

Tiwari, A., Dwivedi, A. K., Dikshit, P. R.

\section{How to cite this article:}

Ripan Chandra Das, G. Somanagouda and Bheiru Singh. 2017. Effect of Integrated Nutrient Management (INM) practices on Growth, Yield and Oil Yield of Safflower (Carthamus tinctorius L.). Int.J.Curr.Microbiol.App.Sci. 6(4): 511-516.

doi: https://doi.org/10.20546/ijcmas.2017.604.061 